Jacek Zjawin ${ }^{1}$

Uniwersytet im. Adama Mickiewicza w Poznaniu

Wydział Teologiczny

\title{
Świętość dla świeckich. Błogosławieni Archidiecezji Poznańskiej
}

Siedmioro świeckich: Edmund Bojanowski, Natalia Tułasiewicz i tzw. „Piątka Poznańska" to trzy różne historie, połączone przez Kościół Archidiecezji Poznańskiej i Eucharystię beatyfikacyjną na placu marsz. Józefa Piłsudskiego, którą celebrował 13 czerwca 1999 św. Jan Paweł II. Niniejszy artykuł zawierający dane hagiograficzne zmierza ku głębszej refleksji i syntetycznym ujęciom mającym ukazać ciągle aktualne modele świętości świeckich. Mimo że we współczesnych prądach duchowości proponuje się odejście od duchowości autorytarnej na rzecz poszukiwania oryginalnej drogi do świętości² to jednak odkrycie w życiorysie wielkopolskiego ziemianina, nauczycielki języka polskiego czy pięciu chłopaków z poznańskiej starówki swoistych rysów świętości, może stać się przyczynkiem do zdefiniowania współczesnego modelu świętości i inspiracją do osobistych poszukiwań na tej drodze.

\section{Błogosławiony Edmund Bojanowski (1814-1871)}

Mówiąc o Edmundzie Bojanowskim w homilii beatyfikacyjnej, św. Jan Paweł II stwierdził:

Ten wielkopolski ziemianin, obdarowany przez Boga licznymi talentami i szczególną głębią życia religijnego, mimo wątłego zdrowia, z wytrwałością, roztropnością i hojnością serca prowadził i inspirował szeroką działalność na rzecz ludu wiejskiego. Wiedziony pełnym wrażliwości rozeznaniem potrzeb, dał początek licznym dziełom wychowawczym, charytatywnym, kulturalnym i religijnym, które wspierały materialnie i moralnie rodzinę wiejską. Pozostając świeckim człowiekiem, założył dobrze w Polsce znane Zgromadzenie Sióstr Służebniczek Bogarodzicy Dziewicy Niepokalanie Poczętej. We wszelkich działaniach kierował się pra-

${ }^{1}$ Ksiądz dr Jacek Zjawin — adiunkt w Zakładzie Katechetyki i Pedagogiki Chrześcijańskiej Wydziału Teologicznego UAM w Poznaniu (jz@amu.edu.pl).

2 Zob. A. Grün, O duchowości inaczej, tłum. K. Zimmerer, Kraków 1996. 
gnieniem, by wszyscy ludzie stali się uczestnikami odkupienia. Zapisał się w pamięci ludzkiej jako „serdecznie dobry człowiek”, który z miłości do Boga i do człowieka umiał skutecznie jednoczyć różne środowiska wokół dobra. W swojej bogatej działalności daleko wyprzedzał to, co na temat apostolstwa świeckich powiedział Sobór Watykański II³.

Życie Edmunda Bojanowskiego zamyka się pomiędzy rokiem 1814 a 1871, pomiędzy Grabonogiem k. Gostynia, gdzie się urodził, i Górką Duchowną k. Leszna, gdzie zmarł. Jest to czas zaborów, pracy organicznej i pracy u podstaw nad odrodzeniem Narodu. Poniżej zostaną przedstawione główne rysy świętości tego wielkopolskiego ziemianina.

\section{Liczne talenty i wątle zdrowie}

Pochodzący z zamożnej rodziny ziemiaństwa wielkopolskiego Edmund Bojanowski uczył się najpierw w domu pod kierunkiem ks. Jana Siwickiego, wikariusza z pobliskiej parafii. Mając 18 lat, wyjechał na studia filozoficzne do Wrocławia, a następnie do Berlina. Studia przerwał z powodu rozwijającej się gruźlicy. Jednak czas ten rozbudził w nim zamiłowanie do literatury. Była to najpierw jego pasja i świadectwo wrażliwości na piękno ${ }^{4}$, a także główny motyw późniejszej działalności edukacyjnej błogosławionego. Edmund chciał wychowywać przez upowszechnianie dziedzictwa kulturowego Ojczyzny, która w tym czasie nie istniała na mapie Europy. Był to także sposób na utrzymanie dzieł charytatywnych, gdyż po wykorzystaniu zasobów odziedziczonych po rodzinie Edmund zarabiał, wydając czasopismo pt.: „Pokłosie. Zbieranka literacka na rzecz sierot”. Publikował w nim teksty literackie tworzone nieodpłatnie przez pisarzy, z którymi utrzymywał przyjacielskie kontakty. „Pokłosie” było także miejscem prezentowania osobistej twórczości literackiej.

\section{Głębia życia religijnego i powołanie do kapłaństwa}

Biorąc do ręki zapiski Edmunda Bojanowskiego wydane w czterech tomach, każdy po 800 stron, czytelnik spodziewa się natrafić na głębokie mistyczne uniesienia w stylu Dzienniczka św. Faustyny Kowalskiej czy Dziejów Duszy św. Teresy od Dzieciątka Jezus. Dziennik Bojanowskiego, przypomina jednak zapiski wiel-

3 Jan Paweł II, Homilia podczas Mszy Świętej beatyfikacyjnej w Warszawie 13 czerwca 1999, Opoka, 24 czerwca 1999, [online] https://opoka.org.pl/biblioteka/W/WP/jan_pawel_ii/homilie/ warszawa_13061999.html [21.03.2018].

${ }^{4} \mathrm{~W}$ zapiskach pojawia się także motyw platonicznej miłości do kobiety, niezrealizowanej z powodu różnicy wyznania. Maria Pohl, w której najprawdopodobniej zakochał się 19-letni Edmund, córka uniwersyteckiego profesora fizyki, była protestantką. 
kich podróżników i odkrywców nieznanych lądów, wytyczając nowe kierunki w duchowości specyficznie męskiej. W notatkach dotyczących kolejnych dni znajduje się zawsze informacja o pogodzie, o codziennych modlitwach, Eucharystii. Informacja pojawia się tam częściej niż duchowa refleksja. Bojanowski następnie opisuje, jakie prace remontowe i sezonowe są wykonywane danego dnia w ochronce, szczegółowo notuje ceny żywca i węgla, które dają nam obraz ówczesnej sytuacji ekonomicznej i gospodarczej. W tych wszystkich, wydawałoby się, ,świeckich” wersach pojawia się co jakiś czas stwierdzenie: ,„[...] Wieczorem do modlitw moich wieczornych dodałem serdeczne modły dziękczynne za dzień tak szczęśliwie spędzony, w którym mi Bóg tyle miłosierdzia i swej cudownej Opatrzności okazał. [...] [19 kwietnia 1853]"5.

To sprawia, że duchowość Bojanowskiego staje się zaczątkiem wspomnianego w papieskiej homilii apostolstwa świeckich, czyli uświęcania świata przez wykonywanie codziennych obowiązków stanu.

O sensie pisania dziennika notuje pod datą 12 października 1854:

\begin{abstract}
Pogoda najśliczniejsza przez cały dzień. Byłem w kościele [...] Miłe w drodze ku Podrzeczu miałem zdarzenie. Spotkaliśmy babkę starą idącą po jałmużnie. Prosząc o wspomożenie, narzekała coś o zgubionym chlebie, ale z tego dobrze nie zrozumiałem i zajęty rozmową z księżmi, nie dałem jej jałmużny, bo miałem tylko kilka srebrników przy sobie. Srebrnik zdawał mi się datkiem za dużym ${ }^{6}$, więc opuściłem sposobność wsparcia staruszki. Bóg przecież pozwolił mi powetować przewinienie. O kilkaset kroków odszedłszy, spostrzegłem na drodze kawał chleba leżący. Podniosłem, pobiegłem za babką i oprócz chleba znalezionego, dałem jej srebrnika, któregom przed chwilą dać żałował. Radość babki i jej głośne błogosławieństwa, ileż były więcej warte, niźli ten srebrnik i posługa! Jest to okoliczność drobna, ale w rozrachunku sumienia ważna, a takim rachunkiem jest dziennik, który dla siebie, nie dla kogo piszę"?.
\end{abstract}

Pod datą 26 kwietnia 1853 roku Bojanowski zapisał: ,[p]ogoda prześliczna i ciepło. Wstawszy przed szóstą i podumawszy trochę przy kawie, poszedłem potem do kościoła [...] Wracając z Instytutu ścieżką przez łąki, usłyszałem pierwsze kumkanie żab w rowie, natrafiłem jaszczurkę snującą się przy ścieżce i pokazały się żółte i brunatne motyle"».

Pod datą 7 lipca tegoż roku czytamy:

Pogoda — nieco tylko zaobłoczone niebo. Wstałem po 6tej. Gdym do kościoła wychodził, spotkał mnie na drodze młody chłopak schorzały, opuchły, jakiś Markiewicz z Gostynia, prosząc, aby go przyjąć na kurację. Odesłałem go do lekarza i burmistrza, za których świadectwem najchętniej go przyjmiem. [...] Przyszedł Muszyński, któremu dałem dziś na kontrakt 15 talarów, które jutro z budowlanych pieniędzy odbiorę. Dotąd wybrał 22 talary. Zro-

\footnotetext{
${ }^{5}$ E. Bojanowski, Dziennik 1853-1871, red, A. i T. Szafrańscy, Warszawa 1999, s. 45.

${ }^{6}$ Okucie okna kosztowało 10 srebrników.

7 Tenże, Dziennik, Wrocław 2009, s. 489.

8 Tamże, s. 64-65.
} 
biłem z nim obrachunek na okna podwójne do domu. Jest okien 21. Okno jedno: drzewo, robota i malowanie (1 talar 10 srebrnych groszy), Okucie (10 srg), Szkło (1 tal, $25 \mathrm{srg}$ ). A zatem jedno okno 2 tal $25 \mathrm{srg}$. Za 21 okien uczyniłoby 59 tal $15 \mathrm{srg}$. Obrachowałem z Muszyńskim także, ile potrzeba będzie gwoździ do parkanu. Wyniosło 54 kop, a kopa po $5 \mathrm{srg}$, czyniłoby zatem 9 tal ${ }^{9}$.

O szczególnej wrażliwości ducha świadczy także tętniące w Edmundzie przez całe życie powołanie do kapłaństwa. Z powodu słabości zdrowia nie mógł jednak tego pragnienia zrealizować. W wieku 55 lat wstąpił do seminarium gnieźnieńskiego, po kilku miesiącach formacji przyjął nawet strój duchowny. Stale pogarszające się zdrowie zmusiło go do powrotu do Poznania, a następnie do Górki Duchownej, gdzie goszczony przez ks. Stanisława Gieburowskiego zakończył ziemskie pielgrzymowanie.

\section{Wsparcie rodziny wiejskiej i zgromadzenie Sióstr Służebniczek}

Błogosławiony Edmund Bojanowski jako osoba świecka założył Zgromadzenie Sióstr Służebniczek Najświętszej Maryi Panny, co w tamtych czasach budziło wiele kontrowersji i niezrozumienia. Pomysł stworzenia zgromadzenia powstał, gdy Edmund zauważył, że opiekunki w ochronkach potrzebują głębszej formacji intelektualnej i duchowej ${ }^{10}$. Cała jego działalność wychowawcza była inspirowana troską o zaniedbane dzieci wiejskie, których liczba nieustannie się zwiększała także z powodu epidemii cholery i innych chorób zakaźnych, nawiedzających ziemie polskie pozostające pod okupacją zaborców. Swoje poglądy wychowawcze, przepojone głębokimi wartościami chrześcijańskimi, Bojanowski oparł na zasadach wyniesionych z domu rodzinnego, zdobytej wiedzy oraz własnych, wnikliwych obserwacjach. Był wyjątkowo dobrze przygotowany pod względem intelektualnym, moralnym i duchowym do kreowania nowej koncepcji wychowania ${ }^{11}$. Wcześniej zapoznał się z systemem wychowawczym starożytnych Greków ${ }^{12}$ oraz metodami stosowanymi we Francji, Niemczech i Czechach. Znał wskazówki Augusta Cieszkowskiego i metodę wychowawczą Friedricha Fröbla.

9 Tamże, s. 117-118.

10 Por. Z. Grocholewski, Bt. Edmund Bojanowski. W dynamizmie twórczej miłości, Poznań 2014, s. 19n.

${ }^{11}$ Por. A. Maj, Wspótczesny kontekst katechetyczny idei pedagogicznych błogosławionego Edmunda Bojanowskiego, materiały z sympozjum Aktualność idei pedagogicznych błogosławionego Edmunda Bojanowskiego i ich implikacje katechetyczne, Poznań 2012, s. 21-31.

12 Por. M. Opiela, Integralna Pedagogika Przedszkolna w systemie wychowania Edmunda Bojanowskiego. Kontynuacja i zmiana, Lublin 2013, s. 31. 
Koniecznym do pozytywnego zakończenia procesu beatyfikacyjnego Edmunda Bojanowskiego przypadkiem, uznanym przez Stolicę Apostolską za cudowny, było uzdrowienie Marii Szmyd ze złośliwego nowotworu kości. W latach 70. licealistce Marii, z powodu raka kości, groziła amputacja nogi po staw biodrowy. Rodzina jednak nie wyraziła zgody na amputację i rozpoczęła wraz z siostrami służebniczkami modlitwę o uzdrowienie za wstawiennictwem bł. Edmunda Bojanowskiego. Pod koniec czerwca 1974 roku dziewczyna odłożyła kule i stanęła na własnych nogach. Uzdrowienie potwierdziły badania kontrolne, przeprowadzane w następnych latach ${ }^{13}$.

Model świętości dostępnej dla świeckich, który zrealizował błogosławiony Edmund Bojanowski, to przede wszystkim oddanie wszystkich talentów i zdolności na rzecz wychowania młodego pokolenia oparte na mocnym fundamencie osobistego życia duchowego. Koncepcja pedagogiczna Bojanowskiego, wpisująca się w pedagogikę integralną, jest realizowana od 160 lat w licznych ochronkach prowadzonych przez Zgromadzenie, które założył. Pomimo zmieniających się warunków społeczno-kulturowych ochronki cieszą się niesłabnącym powodzeniem i są dużą konkurencją dla publicznych i prywatnych oddziałów przedszkolnych $^{14}$.

\section{Błogosławiona „Poznańska Piątka”}

Są wśród tych błogosławionych męczenników również ludzie świeccy. Jest pięciu młodych mężczyzn ukształtowanych w salezjańskim oratorium; [...] Ci błogosławieni męczennicy wpisują się w dzieje świętości Ludu Bożego pielgrzymującego od ponad tysiąca lat po polskiej ziemi $^{15}$.

Tych pięciu młodych mężczyzn to tzw. Poznańska Piątka, czyli: Czesław Jóźwiak, Franciszek Kęsy, Edward Kaźmierski, Jarogniew Wojciechowski i Edward Klinik $^{16}$. Od najmłodszych lat związani z Salezjańskim Oratorium przy ul. Wronieckiej w Poznaniu, byli prawie rówieśnikami. Umierali w wieku od 19 do 23 lat. Dojrzewanie chłopców z Poznańskiej Piątki można umownie podzielić na cztery najważniejsze etapy. Są to kolejno: dzieciństwo w domach rodzinnych, doświadczenie wychowawcze oratorium salezjańskiego (w przypadku Edwarda Klinika także szkoły salezjańskiej w Oświęcimiu), zaangażowanie konspiracyjne (u Czesława Jóźwiaka także udział w wojnie obronnej 1939 roku) oraz ostatnie

13 J. Wiśniewska, Bt. Edmund Bojanowski. Świecki mężczyzna i... zakon dla kobiet, stacja7. pl, 7 sierpnia 2017, [online] https://stacja7.pl/swieci/bl-edmund-bojanowski-swiecki-mezczyzna-zakon-dla-kobiet/ [21.03.2018].

${ }^{14}$ M. Opiela, Integralna Pedagogika Przedszkolna ..., s. 57.

15 Jan Paweł II, Homilia...

${ }^{16}$ Zob. M. Tadrzak-Mazurek, Zwyczajni święci, Poznań 2014. 
dwa lata życia spędzone w hitlerowskich więzieniach ${ }^{17}$. Każdy z nich to inna osobowość i inny charakter. W tym krótkim opracowaniu mogę zwrócić uwagę tylko na najważniejsze elementy ich świeckiej drogi do świętości.

Czesław Jóźwiak urodził się 7 września 1919 roku w Łażynie koło Bydgoszczy. W głęboko wierzącej rodzinie Jóźwiaków żywe były uczucia patriotyczne, które pielęgnował w sposób szczególny ojciec Czesława, były powstaniec wielkopolski i funkcjonariusz policji śledczej. W 1930 roku rodzina przeprowadziła się do Poznania, zamieszkując w czynszowej kamienicy przy ul. Żydowskiej 30. Czesław w wieku 10 lat zaczął uczęszczać do Oratorium przy ul. Wronieckiej 9. Po ukończeniu szkoły podstawowej w 1934 roku zapisał się do Państwowego Gimnazjum im. Św. Jana Kantego w Poznaniu, do którego uczęszczał aż do wybuchu wojny. $\mathrm{Z}$ zachowanych świadectw szkolnych wyłania się obraz spokojnego ucznia, który jednak uczył się średnio. W tym czasie należał również do harcerstwa. Po wybuchu wojny tylko jemu z całej Piątki udało zaciągnąć się na ochotnika do wojska. W Jarocinie dostał się do polskiego pułku piechoty. Po przegranej bitwie pod Kutnem i klęsce wrześniowej powrócił do Poznania, gdzie podjął pracę w firmie malarza Oskara Henfflera przy ul. Podgórnej. W salezjańskim Oratorium spędzał większość wolnego czasu. Z racji wieku i posiadanych cech nazywany był w Oratorium Tatą i rzeczywiście był nieformalnym przywódcą Piątki. Cechy przywódcze łączył z wielką życzliwością i gotowością niesienia pomocy, zwłaszcza młodszym, którymi chętnie się opiekował w czasie wspólnych wyjazdów. Aktywnie udzielał się w zajęciach i grupach oratoryjnych - śpiewał w chórze, występował w przedstawieniach, organizował zawody sportowe, w których sam brał udział. Powoli dojrzewało w nim także pragnienie wstąpienia do Zgromadzenia Salezjańskiego, z którym jednak nie obnosił się publicznie. Jego duchowość zwyczajna i naturalna była owocem żywego uczestnictwa w życiu sakramentalnym, regularnej spowiedzi świętej oraz częstej Komunii18.

Franciszek Kęsy urodził się 13 listopada 1920 roku w Berlinie-Wilmersdorf. W 1921 roku rodzina Kęsych powróciła do Polski i zamieszkała w Poznaniu. W katolickiej rodzinie, w której wspólna modlitwa była na porządku dziennym, Franek najczęściej modlił się z matką i siostrą. W sposób szczególny rozwinęła się w nim pobożność maryjna, którą mógł pielęgnować i rozwijać w Oratorium. Od wczesnych lat szkoły podstawowej był również ministrantem, często służył do Mszy Świętej, podczas której przyjmował Komunię. Młody Franciszek przez najbliższych uważany był za osobę delikatną i wrażliwą. Po ukończeniu szkoły podstawowej pragnął wstąpić do Niższego Seminarium Salezjańskiego w Lą-

17 Zob. R. Sierchuła, J. Wąsowicz, Wierni do końca: studia i materiatyźródtowe o „Poznańskiej Piątce” męczenników II wojny światowej, Poznań 2012.

${ }_{18}$ Por. J. Krawiec, Błogosławieni świadkowie Chrystusa, Kraków 2000, s. 193n. 
dzie, w czym niestety przeszkodziła mu choroba i ogólny słaby stan zdrowia. Wybrał jedno z publicznych gimnazjów w Poznaniu, w którym uczył się dość pilnie, jednak, podobnie jak pozostali młodzieńcy z Piątki, raczej z przeciętnym rezultatem. Po wybuchu II wojny światowej nie udało mu się zaciągnąć do wojska. Dotarł jednak bez broni i munduru wraz z wycofującymi się wojskami aż do Kutna. Po klęsce Armii „Poznań” nad Bzurą powrócił około 20 września do Poznania. Dzięki pomocy Czesława Jóźwiaka podjął pracę w zakładzie malarskim Oskara Henfflera. Jako uczeń szkoły podstawowej, w wieku 13 lat, Franciszek zaczął uczęszczać do Oratorium przy ul. Wronieckiej. Salezjanie, jak również pozostali oratorianie, doceniając jego zaangażowanie i gorliwość, wybrali go na prezesa Towarzystwa św. Jana Bosko, które koordynowało i animowało działalność różnych grup i sekcji istniejących w Oratorium. Franciszek był tym samym organizatorem i animatorem życia religijnego, liturgicznego, kulturalnego i sportowego. Był równocześnie członkiem chóru oraz aktorem w większości spektakli oratoryjnych. Jego pasją, pomimo słabego stanu zdrowia, był sport, zwłaszcza tenis stołowy oraz jazda na rowerze. Obok wielkiej wrażliwości i pobożności wyróżniał się także wesołym usposobieniem oraz dużym poczuciem humoru. Przez swą naturalną radość życia i głęboką wiarę wywierał pozytywny wpływ na życie i postępowanie apostolskie swoich kolegów. Pomimo nieudanej próby wstąpienia do niższego seminarium cały czas pragnął zostać salezjaninem, o czym często i otwarcie mówił. Jego pobożność nie miała jednak w sobie nic ze sztucznej egzaltacji młodych ludzi, którzy wcześnie odkrywają w sobie powołanie do życia duchownego. Jego humor i dystans do zewnętrznych trudności dawał o sobie znać również w czasie uwięzienia — podnosił innych na duchu i wprowadzał nadzieję w beznadziejną sytuację szykan i tortur więziennych. Pomimo żywej wiary i pięknych pragnień, podobnie jak każdy młody człowiek, miał swoje wady i słabości ${ }^{19}$.

Edward Kaźmierski ${ }^{20}$ urodził się 1 października 1919 roku w Poznaniu. Ojciec, z zawodu szewc, zmarł w 1923 roku. Rodzina Kaźmierskich zajmowała skromne, jednopokojowe mieszkanie w kamienicy przy ul. Łąkowej. W 1926 roku Edward rozpoczął naukę w szkole powszechnej, a przez następne lata kształcił się w trzech kolejnych szkołach wydziałowych, które ostatecznie ukończył w 1937 roku. Jako uczeń szkoły podstawowej zapisał się do salezjańskiego Oratorium, do którego uczęszczał aż do chwili zamknięcia go przez władze niemieckie. Od 1938 roku rozpoczął pracę jako uczeń w zawodzie ślusarz-mechanik w zakładach samochodowych „Brzeski-Auto”. W tym czasie uczęszczał również do Dokształcającej Szkoły Zawodowej im. Działyńskich. We wrześniu

\footnotetext{
19 Por. tamże, s. 233n.

20 Por. tamże, s. 211 n.
} 
1939 roku, podobnie jak koledzy z Oratorium, próbował zaciągnąć się do wojska. Po klęsce bitwy nad Bzurą powrócił do Poznania, gdzie na powrót podjął pracę w zakładach samochodowych. Eda, bo tak nazywany był w Oratorium Kaźmierski, zapisał się w pamięci swoich oratoryjnych kolegów jako wspaniały śpiewak, muzyk, aktor, sportowiec i znawca samochodów, a przy tym wyjątkowo pobożny i głęboko wierzący kolega. Niezwykłym świadectwem jego młodzieńczych lat są pamiętniki, które pisał przez ponad trzy lata od 1936 do 1939 roku. Pamiętniki te, zostały wydane w 1990 roku pod tytułem Dzienniczek Edy Kaźmierskiego i są niezastąpionym świadectwem dojrzewania psychicznego i duchowego ich autora. $\mathrm{Na}$ ich stronach możemy poznać jego młodzieńcze marzenia i zainteresowania, pierwsze porywy serca i zawody miłosne, opis życia oratoryjnego niejako „od kuchni”, ale jednocześnie bardzo dojrzałe i poważne treści odnoszące się do życia wiary, problemów rodzinnych czy obaw związanych z trudną sytuacją Polski. Niezwykłe jest to, że już jako siedemnastolatek, przeżywając młodzieńcze bunty i kryzysy, szukał rozwiązania swoich trudności w Bogu, co zaowocowało całkowitym oddaniem się w Boże ręce w czasie uwięzienia i w obliczu śmierci. Był świadomy swoich ułomności. Pobożność Edy nie miała w sobie nic ze sztucznej egzaltacji, jego wiara wyrażała się w sposób radosny i spontaniczny, ale jednocześnie bardzo dojrzały. Jako uzdolniony śpiewak, którego koledzy z Oratorium nazywali Kompozytorem, zachwycał się postacią Jana Kiepury, którego udało mu się posłuchać w czasie wizyty artysty w Poznaniu. Namiętnie chodził do kina, teatru, opery czy na koncerty, które, jak sam mówił: „ciągnęły go jak pszczołę do kwiatu". Edek, jak każdy chłopak w jego wieku, skupiał uwagę na płci przeciwnej. W pamiętniku często wspominał, że podobały mu się blondynki o usposobieniu miłym i delikatnym, ale lubił także dziewczyny o oczach czarnych i włosach ciemnych. Wybór tej jedynej nastręczał mu niemałych problemów. Dzięki zachowanym pamiętnikom postać Edy wydaje się najwyrazistsza z całej Piątki. Jego świętość urzeka naturalnością, spontanicznością oraz radością życia, które połączone było z głęboką wiarą i dojrzałością wyborów życiowych ${ }^{21}$.

Jarogniew Wojciechowski urodził się 5 listopada 1922 roku w Poznaniu w ubogiej rodzinie mieszkającej w jednej z czynszowych kamienic przy ul. Święty Marcin. Ojciec Jarogniewa z powodu choroby alkoholowej w 1933 roku opuścił rodzinę. Opieką i wychowaniem Jarogniewa i jego siostry zajęła się matka, która, pozostając w separacji z mężem, nie zawarła nowego związku. Chrześcijańskie wychowanie, które Jarogniew odbierał w domu, było pogłębiane i umacniane w poznańskim Oratorium, do którego zapisał się w 1932 roku po przystąpieniu do Pierwszej Komunii Świętej. Po ukończeniu sześciu klas szkoły podstawowej rozpoczął naukę w Gimnazjum im. A. Mickiewicza w Poznaniu, z której jednak

\footnotetext{
${ }^{21}$ Por. tamże, s. 212.
} 
po roku musiał zrezygnować z powodu choroby matki oraz trudności finansowych rodziny. Pragnąc pomóc matce oraz siostrze, zapisał się do Rocznej Szkoły Przysposobienia Kupieckiego w Poznaniu. Po ukończeniu kursu zawodowego, w wieku 16 lat, zawarł umowę o naukę i pracę w drogerii i perfumerii Stanisława Dyczkowskiego w Poznaniu. Zarobki oferowane Jarogniewowi, chociaż nie były zbyt wysokie, to jednak rodzinie Wojciechowskich niosły znaczącą pomocą materialną. We wrześniu 1939 roku, za zgodą matki, mając zaledwie 17 lat, zgłosił swoją gotowość do wstąpienia do wojska. Po klęsce kampanii nad Bzurą wrócił do okupowanego już przez Niemców Poznania. W nowej okupacyjnej rzeczywistości musiał podjąć pracę przymusową, co jednak nie przyczyniło się do zerwania łączności z Oratorium i dawnymi kolegami. Obecność Jarogniewa w Oratorium początkowo wiązała się głównie z zabawą i ministranturą w kościele salezjańskim. Z biegiem czasu, mimo że był najmłodszy w gronie Piątki, zaczął na równi ze starszymi kolegami angażować się w animowanie życia oratoryjnego. Brał udział w przedstawieniach, zawodach sportowych, na koloniach letnich pełnił funkcję opiekuna, wraz z członkami Towarzystwa św. Jana Bosko oraz Towarzystwa Niepokalanej organizował uroczystości liturgiczne i oratoryjne. Posiadał również talent muzyczny, który rozwijał pod czujnym okiem matki, nauczycielki muzyki. Swoje zdolności muzyczne często prezentował w Oratorium, grając na fortepianie i występując w chórze. Wśród kolegów z Oratorium postrzegany był jako spokojny i refleksyjny, ale mimo to wesoły i skory do żartów. Ważnym czynnikiem wpływającym na osobowość Jarogniewa była rodzinna tragedia spowodowana alkoholizmem i odejściem ojca oraz ofiarna postawa matki. Te doświadczenia kształtowały w nim postawę odwagi, męstwa i gotowości do poświęcenia się. Radosna pobożność, której uczyli swoich wychowanków w Oratorium salezjanie, przyniosła owoc w postaci pięknego, choć niełatwego życia i męczeńskiej śmierci² ${ }^{22}$.

Edward Klinik urodził się 29 lipca 1919 roku w niemieckim Bochum, dokąd rodzina wyemigrowała za pracą. Po odzyskaniu niepodległości Klinikowie powrócili do Polski i zamieszkali w Poznaniu przy ul. Zielnej. Rodzice Edwarda odznaczali się głęboką wiarą i pobożnością, która stała się również udziałem trójki ich dzieci. Edward po raz pierwszy zetknął się z salezjańskim Oratorium jako uczeń szkoły podstawowej. Rodzice, widząc pozytywny wpływ salezjańskiego sposobu wychowania, wysłali go we wrześniu 1933 roku do Salezjańskiego Gimnazjum im. Jana Bosko w Oświęcimiu, które ukończył w 1937 roku. Początek pobytu w nowej szkole był dość trudny dla nieśmiałego z natury Edwarda. Z czasem jednak zaaklimatyzował się w salezjańskiej placówce, zostając nawet prezesem Sodalicji Mariańskiej oraz przewodniczącym samorządu uczniowskiego.

\footnotetext{
${ }^{22}$ Por. tamże, s. 271 n.
} 
W pamięci kolegów i nauczycieli z tamtego okresu pozostał jako uczeń przeciętny, jednak cechujący się dużą życzliwością i uczynnością. Widoczna była również jego naturalna pobożność i głęboki kult Matki Bożej. Po powrocie do Poznania w 1937 roku kontynuował naukę w Gimnazjum im. Bergera, w którym zdał maturę w 1939 roku. Po czterech latach nieobecności powrócił również do poznańskiego Oratorium, włączając się na nowo w życie oratoryjne. We wrześniu 1939 roku, za zgodą rodziców, próbował wstąpić jako ochotnik do Wojska Polskiego. Nie udało mu się jednak otrzymać munduru ani broni. Wraz z wycofującym się wojskiem dotarł, podobnie jak koledzy z Oratorium, do Kutna i powrócił do Poznania. Okupacyjna rzeczywistość zmusiła go do podjęcia pracy w firmie budowlanej „Urbaniak” przy Drodze Dębińskiej. Pierwsze lata pobytu w poznańskim Oratorium, czyli okres od 1929 do 1933 roku, wiązały się dla Edwarda głównie z zabawą i nauką oferowaną przez salezjanów. Po powrocie do Poznania w 1937 roku na nowo zaangażował się w życie oratoryjne. Czerpiąc z doświadczenia nabytego w Oświęcimiu, włączył się wówczas w działalność religijno-liturgiczną, teatralną oraz sportową, organizując akademie i przedstawienia. Podobnie jak pozostali koledzy śpiewał także w chórze. Pod pozorną nieśmiałością Edwarda kryła się prawdziwa głębia ducha, która wyraziła się szczególnie w czasie uwięzienia i w obliczu śmierci. Głęboka wiara, którą wyniósł z domu, dojrzewała zarówno w salezjańskiej szkole w Oświęcimiu, jak i w poznańskim Oratorium ${ }^{23}$. Swoją drogę życia wewnętrznego oparł na Naśladowaniu Chrystusa Tomasza à Kempis, a w więzieniu stworzył własny modlitewnik, który jest świadectwem jego osobistej relacji z Bogiem.

Dopiero w ostatnich latach dzięki dokumentom ujawnionym przez Instytut Pamięci Narodowej można było rozwinąc konspiracyjny i patriotyczny wątek tych pięciu biografii ${ }^{24}$. Proces ich duchowego dojrzewania doskonale dokumentują kolejne listy wysyłane przez nich do domów rodzinnych z więzień we Wronkach, w Berlinie-Spandau, w Neukölln, w Dreźnie ${ }^{25}$. Najmocniejszym świadectwem ich świętości są pożegnalne listy do rodzin napisane pół godziny przed wykonaniem wyroku śmierci przez zgilotynowanie na dziedzińcu więzienia w Dreźnie, dokąd dotarli po kilkuletniej tułaczce i brutalnych przesłuchaniach. Świadkiem pisania tych listów, ostatnim spowiednikiem i towarzyszem w momencie egzekucji był ojciec Franz Bänsch. Ten kapłan ze zgromadzenia Oblatów Maryi Niepokalanej zaraz po powrocie na plebanię zapisał na odwrotnej stronie wezwania do więzienia: „[d]ziś przeszli do wieczności ludzie święci”. Niemiecka machina wojenna w swojej precyzji i porządku dostarczyła te ostatnie „listy spod gilotyny" wraz z rzeczami osobistymi do rodzin Poznańskiej Piątki. Przebi-

\footnotetext{
23 Por. tamże, s. 249-251.

24 Zob. R. Sierchuła, J. Wąsowicz, Wierni do końca...

25 Zob. M. Tadrzak-Mazurek, Zwyczajni święci, s. 156-207.
} 


\section{ja z nich dojrzała wiara, spokój połączony w przedziwny sposób z entuzjazmem oczekiwania na spotkanie z Bogiem.}

Właśnie dzisiaj, tj. 24, w dzień Maryi Wspomożycielki otrzymałem Wasze listy. Przychodzi mi rozstać się z tym światem. Powiadam wam, moi drodzy, że z taką radością schodzę z tego świata, więcej aniżeli miałbym być ułaskawionym. Wiem, że Maryja Wspomożycielka Wiernych, którą całe życie czciłem, wyjedna mi przebaczenie u Jezusa. Przed chwilą wyspowiadałem się i zaraz przyjmę Komunię Świętą do swego serca. Ksiądz będzie mi błogosławił przy egzekucji. Poza tym mamy tę wielką radość, że możemy się przed śmiercią wszyscy widzieć. Wszyscy koledzy jesteśmy razem w jednej celi. Jest 7.45 wieczorem. O godz. 8.30, tj. pół do dziewiątej zejdę z tego świata. Proszę was tylko nie płaczcie, nie rozpaczajcie, nie przejmujcie się, Bóg tak chciał. [...] Do zobaczenia się w niebie. Wasz syn i brat. Czesław ${ }^{26}$.

Nadeszła chwila pożegnania się z Wami i to właśnie w dniu 24 sierpnia, dzień Maryi Wspomożycielki Wiernych. Och jaka to radość dla mnie, że już odchodzę z tego świata i tak jak powinien umierać każdy. Byłem właśnie przed chwilą u spowiedzi świętej, za chwilę zostanę posilony Najświętszym Sakramentem. Bóg Dobry bierze mnie do siebie. Nie żałuję, że w tak młodym wieku schodzę z tego świata. Teraz jestem w stanie łaski, a nie wiem czy później byłbym wierny mym przyrzeczeniom Bogu oddanym. Kochani Rodzice i Rodzeństwo bardzo Was przepraszam raz jeszcze z całego serca za wszystko złe i żałuję za wszystko z całego serca, przebaczcie mi, idę do Nieba, do zobaczenia, tam w Niebie będę prosił Boga. [...] Wasz syn Franek ${ }^{27}$.

Moja najukochańsza Matusiu i najmilsze siostry. [...] O dziękujcie Najłaskawszemu Zbawcy, że nie wziął nas nieprzygotowanych z tego świata, lecz po pokucie, zaopatrzonych Ciałem Jezusa w dzień Maryi Wspomożycielki Wiernych. O dziękujcie Bogu za Jego niepojęte miłosierdzie. Dał mi spokój. Pogodzony z Jego Przenajświętszą Wolą schodzę za chwilę z tego świata. Wszak On tak dobry, przebaczy nam. Dziękuję Tobie, Mamusiu za błogosławieństwo. Bóg tak chce. Żąda od Ciebie tej ofiary. O złóż ją, Matusiu, za mą duszę grzeszną. [...] Przepraszam wszystkich, którym zawiniłem i proszę pokornie o przebaczenie. Do upragnionego zobaczenia w niebie. Wasz kochający syn i brat. Edek. Zostańcie z Bogiem!28.

Najdroższa Liduś! [...] jestem pewny, że będziesz się raczej ze mną cieszyć a nie rozpaczać, bo dostępuję nadzwyczajnej łaski Bożej i odchodzę poznawszy gruntownie moją przeszłość, bez najmniejszego żalu. Świat, ludzi i życie również poznałem i dlatego dzisiaj, Kochana Liduś, bądź pewna, że Ty sama na tej ziemi nie zostajesz. Ja i Mamusia jesteśmy zawsze przy Tobie [...] Odchodzę zjednoczony z Jezusem przez Komunię świętą. W ostatniej mojej Komunii świętej myślę o Tobie i ofiaruję ją za Ciebie i za siebie z tą nadzieją, że cała nasza rodzina bez wyjątku będzie szczęśliwa tam u Góry. Proszę Cię, proś Ojca naszego, o przebaczenie wszystkiego, co uczyniłem złego z tym zapewnieniem, że zawsze Go kochałem. [...] Idę już i oczekuję Cię tam w Niebie. Zawsze kochający Cię brat. Jarosz ${ }^{29}$.

Dziwne są wyroki Boże, lecz musimy się zawsze z nimi pogodzić, gdyż wszystko to jest dla dobra naszej duszy. Moi kochani, dziwna jest wola Jezusa, że zabiera mnie już w tak młodym wieku do siebie, lecz jakże szczęśliwa będzie dla mnie ta chwila, w której będę miał opuścić tę ziemię. [...] Do ostatniej chwili z moją silną wiarą w sercu idę spokojnie do wieczności, gdyż

\footnotetext{
26 Tamże, s. 140-141.

27 Tamże, s. 142.

28 Tamże, s. 141-142.

29 Tamże, s. 143-144.
} 
nie wiadomo co by mnie tutaj na ziemi czekało. Was proszę moi kochani o modlitwę za moją grzeszną duszę, proszę Was o przebaczenie mych grzechów młodości. Ściska Was i całuje z całego serca i z całej duszy. Was zawsze kochający Syn i brat. Edzio ${ }^{30}$.

Nie byłoby więc ich męczeńskiej śmierci, gdyby nie wcześniejsze życie oparte na ideałach przekazanych w rodzinnych domach oraz w salezjańskim Oratorium. Jak zauważa ks. Pascual Chávez Villanueva, następca ks. Bosko: „ta beatyfikacja pokazała, obok łaski Ducha Świętego, również jakość, skuteczność i bogactwo wychowania salezjańskiego, które dzięki systemowi zapobiegawczemu pomaga młodym dojrzewać do wielkich życiowych wyborów, aż po uczynienie świętości planem życia"31. Postępowanie tych pięciu młodzieńców stało się wyrazem salezjańskiej świętości, która jest:

prosta i trudna zarazem. Oznacza bowiem bycie z Bogiem w codzienności, oznacza śmiały i zawsze możliwy przystęp do Jezusa, polega na pełnym nadziei i pogodnym stosunku do rzeczywistości $[\ldots]$ ta prostota jest jednak okupiona trudem wcześniejszego wejścia na wielką głębię wiary, trudem ufania Bogu i życia w świetle Jego miłości ${ }^{32}$.

\section{Błogosławiona Natalia Tułasiewicz (1906-1945)}

Dziś właśnie świętujemy zwycięstwo tych, którzy w naszych czasach oddali życie dla Chrystusa, aby posiąść je na wieki w Jego chwale. Jest to zwycięstwo szczególne, bo dzielą je duchowni i świeccy, młodzi i starzy, ludzie różnego pochodzenia i stanu [...]”33.

Błogosławiona Natalia, jedna z tych świeckich, którzy oddali życie dla Chrystusa, jest ciągle bardziej znana jako wybitny pedagog i artystka. Mniej mówi się o jej działalności konspiracyjnej, a dopiero w ostatnich latach pojawiają się opracowania o jej głębokim życiu duchowym ${ }^{34}$. Dzieciństwo spędziła w Galicji pod zaborem austriackim. Do Wielkopolski przybyła wraz z rodzicami z Rzeszowa w poszukiwaniu poprawy sytuacji materialnej w 1921 roku. Bliscy zwali ją „mądrą Niusią”, otoczenie dostrzegało wysoką inteligencję i zdolności organizacyjne. Uczyła się gry na skrzypcach, po kryjomu pisała pierwsze wiersze. Była jednak wątłego zdrowia i wielokrotnie przechodziła poważne zabiegi operacyjne. To właśnie problemy ze zdrowiem zaważyły później na wyborze studiów wyż-

30 Tamże, s. 143.

31 P. Chávez, Zwiastunowie poranka, „Don BOSCO. Magazyn salezjański”, 7/8 (2002), s. 2.

32 J. Mikuła, Jak wychować świętych, „Don BOSCO. Magazyn salezjański” 6 (2006), s. 4.

33 Jan Paweł II, Homilia...

${ }^{34}$ Zob. A. Rzesoś, Błogosławiona Natalia Tułasiewicz. Droga do Męczeństwa (rozprawa doktorska), AMUR - Adam Mickiewicz University Repository, 23 listopada 2015, [online] https:// repozytorium.amu.edu.pl//handle/10593/14036 [23.07.2018]. 
szych, kiedy Natalia, nie mogąc realizować zainteresowań medycyną, biologią i przyrodą, oddała się studiowaniu literatury. Lata młodzieńcze wypełniało Natalii poszukiwanie sensu życia. Po śmierci młodej kuzynki narkomanki uświadomiła sobie, jako szesnastoletnia dziewczyna, że „żadne ziemskie dobro nie wypełni tak duszy, aby nie tęskniła za czymś piękniejszym, [...] tylko Bóg może być dobrem ostatecznym, poza które nie sięgamy tęsknotą" ${ }^{35}$. Odpowiadając sobie na pytanie: „po co żyć”, nakreśliła kontury swojej misji życiowej: „aby drugim czynić dobrze"36. W 1926 roku rozpoczęła studia polonistyczne i muzykologiczne na Uniwersytecie Poznańskim ${ }^{37}$. Warto podkreślić, że w dwudziestoleciu międzywojennym dostępność studiów wyższych dla kobiet była mocno ograniczona. W 1931 roku ukończyła studia bardzo dobrą obroną pracy dyplomowej „Mickiewicz a muzyka”. Obok literatury wielką pasją jej życia była bowiem muzyka, która — jak zapisała w swoich notatkach — ,idzie za rękę z książką"38. Jako magister filologii polskiej utrzymywała kontakt z Uniwersytetem, uczestnicząc w seminariach, i planowała pracę doktorską o pisarzu katolickim Karolu Hubercie Rostworowskim ${ }^{39}$. Na początku studiów poznała studenta Janka Patokę i zakochała się w nim od pierwszego wejrzenia. Narzeczony okazał się komunistą, z którym dyskutowała o sprawach ideologicznych podczas pracy w zarządzie Koła Polonistów ${ }^{40}$. Ich ośmioletnią znajomość - określoną przez Natalię jako „okres nieustannej walki o światopogląd i duszę" — zakończyło zerwanie zaręczyn, które w zapiskach błogosławionej pojawia się nie tyle jako dramat życiowy, ale bardziej jako decyzja wynikająca z wyższych wartości. W roku 1927 Natalia doświadczyła bolesnej żałoby z powodu śmierci najstarszej siostry Maryli. W tej trudnej sytuacji rodzinnej potrafiła znaleźć słowa pociechy dla bliskich, przypominała wszystkim, że spotkają się razem w niebie. Natalia z własnego wyboru podjęła drogę życia w stanie bezżennym, gdyż, jak mawiała: „,[w]alor samotności stwarza niesłychane horyzonty działania"41. Pracowała zawodowo, najpierw w prywatnej szkole katolickiej św. Kazimierza, a potem w Gimnazjum

${ }^{35}$ N. Tułasiewicz, Poprzez ziemię ukochałam niebo: fragmenty zapisków 1938-1943, Poznań 2015, s. 93.

36 Tamże.

37 Zob. tamże, s. 7.

38 „Książka odradza mnie duchowo, odświeża, kąpie, pobudza, prowokuje, nie daje wytchnienia w tym najlepszym sensie, przypomina ciągle, że duch nie zna zmęczenia, że znużenie ogarnia tylko ciało, a istotą ducha jest wieczny ruch, wieczne tworzenie. Muzyka w moim życiu duchowym czyni ład. Uświadamia nieuświadomione, uczy odróżniać rzeczy istotne od przypadków mniej ważnych, zabiega pilnie, aby moje człowieczeństwo nie kurczyło się do dziedziny intelektu tylko"; tamże, s. 34.

39 Por. tamże, s. 15.

40 Por. tamże, s. 21, 94.

${ }^{41}$ „Muszę szukać oparcia w instytucji, która swoją siłą moralną zastąpiłaby jej siły, jakie kobiety czerpią z małżeństwa. Widzę to w zakonie, ale świeckim [...]”; tamże, s. 99. 
i Liceum Sióstr Urszulanek. Zapisała się w pamięci ludzkiej jako nauczyciel nowoczesny, niezwykle twórczy, żyjący aktualnymi wydarzeniami ${ }^{42}$. Zdobywała autorytet przez stawianie sobie coraz to nowych i wyższych wymagań, zarówno w życiu osobistym, jak i zawodowym. Natalia interesowała się postaciami świętych i ideałem świętości świeckiej. Szukała możliwości uświęcania świata współczesnego w jego wymiarach powszednich ${ }^{43}$. W zapiskach notowała: „,n]ie oddzielam życia najbardziej szarego od ideałów, ku którym podążam. Wszystko, praca, nauka, sen, przyjemność, jedzenie, wszystko wciągam w swój program doskonalenia się"44. Myśląc o trzecim zakonie, nie wyobrażała sobie jednak tego, by dla przestrzegania jego reguły porzucić np.: kino i teatr. Chciała nie tyle tworzyć sprzyjające dla wiary warunki w zaciszu swojego serca, ale nieść Chrystusa w środowiska ludzi odwróconych od Niego. To był jej nowoczesny, oryginalny program nowej ewangelizacji ${ }^{45}$. Według tego programu przykładny chrześcijanin ma nie tylko obowiązek cierpieć, ale ma także równorzędny obowiązek przykładnie się radować ${ }^{46}$.

W listopadzie 1939 roku dziewięcioosobową rodzinę Tułasiewiczów wysiedlono z mieszkania do obozu przejściowego na ul. Głównej w Poznaniu, by stąd wywieźć ich do Ostrowca Świętokrzyskiego. W czasie obozowej kwarantanny, leżąc na słomie z powodu bardzo dokuczliwego bólu żołądka, wśród lamentu kobiet i płaczu głodnych niemowląt, w duszy deklarowała Panu Jezusowi swoją gotowość pójścia z Nim na Kalwarię ${ }^{47}$. Tułaczka wojenna prowadziła Natalię i jej rodzinę przez Ostrowiec Świętokrzyski do Krakowa. W zimie 1940 roku umarł w szpitalu po ciężkiej chorobie ojciec Natalii, która czuwała przy nim dzień i noc ${ }^{48}$. Po jego śmierci pocieszała bliskich, podkreślając, że narodził się dla nieba. W 1943 roku wyjechała jako pełnomocnik-emisariusz Rządu Londyńskiego i świecki apostoł do Hanoweru, by pomagać przerażonym i zagubionym pracownikom przymusowym. Słaba fizycznie, silna duchem, po wielu godzinach codziennej, ciężkiej pracy w fabryce, realizowała w skrajnie trudnych warunkach posługę religijno-społeczno-oświatową ${ }^{49}$. Natalia jako osoba solidna i dobrze zorganizowana godziła codzienną trzyzmianową pracę z pracą twórczą i apostol-

42 Por. B. Judkowiak, „Przyjmij mnie na nowo do swej klasy” (nauczyciele „w szkole” błogosławionej Natalii) [w:] Blask świadectwa. Błogosławiona Natalia Tułasiewicz, Poznań 2013, s. 11-43.

${ }^{43}$ Por. N. Tułasiewicz, Poprzez ziemię ukochałam niebo..., s. 7.

44 Tamże, s. 191.

45 Por. tamże, s. 100.

46 Por. tamże, s. 103.

47 Por. tamże, s. 61.

48 Por. tamże, s. 90.

49 J. Podlaszczak, Trudne czasy rodza świętych nauczycieli, „Kwartalnik Edukacyjny”, 4 (2007) 51, s. 67-72; B. Judkowiak i in., Blask świadectwa. Błogosławiona nauczycielka Natalia Tułasiewicz, Poznań 2013, s. 11-43. 
ską — omawianiem katechez z koleżankami z baraku. Głosiła Ewangelię również spotkanym w fabryce Niemcom, którzy zapomnieli o Bogu. W wyniku dekonspiracji po wizycie nieostrożnego kuriera z Polski więziono ją w Hanowerze, potem w Kolonii. Przechodziła przez bestialskie tortury w czasie śledztwa. We wspomnienie św. Andrzeja Boboli została tak pobita, że krew tryskała z chorych, powiększonych węzłów chłonnych, a na ciele nie było ani jednego jasnego miejsca. Nikogo nie wydała, a za oprawców się modliła. Po przesłuchaniu, dopiero po modlitwie dziękczynnej kładła się spać. Zachowały się jej listy wysyłane do rodziny z tego okresu, w których nie pisała o swoim cierpieniu, by nie martwić bliskich. Niektóre informacje przekazywała w sposób zakamuflowany, wykorzystując doskonałą pamięć i twórczą wyobraźnię.

W jej duchowości łatwo rozpoznać cechy karmelitańskie. Natalia wielokrotnie powoływała się na „lekcję nocy ciemności” św. Jana od Krzyża. Od dziecka stanem naturalnym była dla niej modlitwa wewnętrzna. Lektura św. Teresy od Jezusa pomogła jej odkryć wiele punktów stycznych jej życia duchowego z tą świętą. Systematycznie studiowała św. Augustyna i św. Tomasza z Akwinu ${ }^{50}$. Stworzyła też szkic własnych komentarzy do Księgi Psalmów, które odczytywała w kontekście wydarzeń wojny i okupacji ${ }^{51}$. Modlitwa według niej nie może być oddzielona od czynu, gdyż wtedy pozostaje ucieczką od rzeczywistości i kwietyzmem. Dlatego Natalia starała się swoją wiarę uczynić inspiracją do wielowątkowej działalności społeczno-edukacyjnej ${ }^{52}$. Ważnym rysem jej duchowości jest całkowite zawierzenie Bożej Opatrzności, zwłaszcza w chwilach wojennej tułaczki i obozowej gehenny ${ }^{53}$. Była zafascynowana przyrodą, która powodowała wewnętrzne uniesienie duszy ku Bogu ${ }^{54}$. Bardzo mocnym świadectwem jej drogi do świętości są zachowane listy. W korespondencji z czasów przedwojennych i początku wojny zauważyć można pobożność rozwijającą się w kierunku mistyki:

Pilnuję codziennej Mszy św. i Komunii św. To jest mój oddech [...] Gdy z powodu ulewnego deszczu nie poszłam wczoraj do kościoła, czułam się zubożona — wydało mi się jakbym była jednym z członków wszechświatowej orkiestry i oto przestałam grać, gdy cały zespół dźwiga melodię wzwyż [...] — na pozór nic — któż by zauważył brak jednego instrumentu w zespole ogólnym — ale przecież On, Dyrygent wszechświatowej symfonii czuwa i brak najmniejszego $\mathrm{z}$ instrumentów nie jest Mu obojętny [23 sierpnia 1938 $]^{55}$.

${ }^{50}$ Por. N. Tułasiewicz, Poprzez ziemię ukochałam niebo..., s. 8, 127.

${ }^{51}$ Zob. D. Tułasiewicz, B. Judkowiak, Przeciw barbarzyństwu. Listy - Dzienniki - Wspomnienia, Poznań 2013, s. 83-119.

${ }_{52}$ Por. N. Tułasiewicz, Poprzez ziemię ukochałam niebo..., s. 20.

${ }_{53}$ Por. tamże, s. 85.

${ }^{54}$ Por. tamże, s. 34, 91.

55 D. Tułasiewicz, B. Judkowiak, Przeciw barbarzyństwu ..., s. 23. 
Wiara Natalii dojrzewa w trudnościach wojennej tułaczki: „,[o]kres wojny traktuję osobiście jako czas cennych, choć trudnych rekolekcji. Tacy przecież jak ja winni po wojnie stanąć w awangardzie walki o nowe oblicze już nie tylko Polski, ale świata [25 października 1942] $]^{56 "}$. Notatki do Psalmów wojny natomiast, jako swoisty komentarz egzegetyczny, ujawniają jej głębokie przemyślenia: „[b]yłoby to pięknie [...] gdybyśmy tych kilka tysięcy gestapowców i innych mogli razem zgromadzić po zwycięstwie i powiedzieli im: «Teraz my jesteśmy silni. Możemy z wami postąpić tak, jak wy z nami. Ale stać nas na co innego. Jesteście wolni. Idźcie do swoich i niech życie dalsze pouczy was najlepiej w czym zbłądziliście». Taki wyrok także wstrząsa duszą [17 sierpnia 1943] ${ }^{57 ”}$.

W listach z czasów działalności konspiracyjnej i więzienia odkrywamy Natalię pełną entuzjazmu i sprytu, odwagi i samozaparcia:

Moi Ziuteczkowie Najmilsi! ${ }^{58}$

[...] Co się nie powyrabiało przez tych kilka miesięcy! Tyle zmian! Wszystko osobiście znoszę dobrze i da Bóg niedługo ucieszymy się sobą na ulicy Śniadeckich. Na ulicy Młyńskiej w Hanowerze doręczono mi tuż przed wyjazdem tu paczkę od Was. Najserdeczniej i najmocniej dziękuję, szkoda tylko, że tu nie mogłam jej wykorzystać, ale powetuję sobie kiedyś tę stratę, gdy zajadać się będę z Wami pysznościami, jak niegdyś. [...] Pan trapi, Pan też i koi, pamiętajcie! O mnie się nie troskajcie, nie mogą jakoś zmóc mię trudy. [...] Może wkrótce mój adres się ustabilizuje, to będziecie mogli do mnie pisać.

Całuję najmocniej

wasza Nata [7 września 1944$]^{59}$.

Zachował się także jeden z ostatnich listów, w których Natalia, pomimo beznadziejnej sytuacji, dostrzega ciągle sens życia i potrafi się nim cieszyć:

Droga przyjaciółko moja, Oluniu!

Znowu się odzywam. [...] Jakoś dotychczas nie biorą nas na transport, może to wprawdzie nastąpić lada dzień ze względu na ogólną sytuację. Jest mi tu nie najgorzej, mam względną swobodę poruszeń; w czasie wędrówek do bunkra pobliskiego, gdzie nocujemy, mam trochę przechadzki; za dnia na podwórzu barakowym widzę piękne drzewa, trochę grządek, jeszcze zielonych, słowem, najgorsze już najprawdopodobniej mamy za sobą. Od 10 maja, tj. od czasu wyjazdu tu, towarzyszy mi jedna z najlepszych koleżanek z Hanoweru, więc we dwie lżej nam nieść niespodzianki wojny. Poza tym poznaję tu coraz inne koleżanki, czasem bardzo różne, ale zżywamy się po jakimś czasie, a wspólna ufna modlitwa najlepiej nas jednoczy. Najtrudniejsza była dla mnie pierwsza połowa maja, w Hanowerze u Mont[elupich ${ }^{60}$ przypadł

56 Tamże, s. 71.

57 Tamże, s. 117.

${ }^{58}$ Nata jest w więzieniu i zagęszcza aluzje z racji cenzury niemieckiej..., „Ziuteczkowie” to rodzina brata Józefa; przed wojną Natalia mieszkała z rodziną w Poznaniu przy ul. Śniadeckich 30 m. 8; czytelna jest, przygotowana wcześniej przypomnieniem Poznania, aluzja do uwięzienia — na ul. Młyńskiej w Poznaniu był areszt.

59 Tamże, s. 229.

${ }^{60}$ Przy ulicy Montelupich w Krakowie było więzienie, osławiona katownia gestapo. 
mi wypoczynek dziesięciodniowy, bo przestałam pracować 29 kwietnia. Te dni za łaską Bożą przeszły znośnie, następny dopiero etap był znacznie trudniejszy, ale Bóg zawsze cudownie nas wspierał. Jeszcze w Hanowerze u Mont. miałam króciutką operację na gruczoł limfatyczny szyjny lewy nagle od marca znacznie powiększony. [...] Choć podobało się Bogu pomnożyć mi od pięciu miesięcy trudy wojny, znoszę je cierpliwie, wdzięcznym sercem przyjmując niezliczone łaski, które pozwalają mi doróść do kolei losu, takich bądź, co bądź dynamicznych. [...] Pomyśl, trzy i pół miesiąca nie widziałam słońca, powietrza ledwie mogłam łyknąć (śpiewka o tym mówi nasza: ,jedzenie kacze, okienko dla szczura, ale wołamy hurra!”), jednak mię nie zmogło. Miałam ciężki świerzb. Już zaleczony, ale skóra ciągle mię swędzi, bo muszę spać w codziennym ubraniu. W ogóle, opowieści będzie bez końca i to jakich! oddana sercem Nata [26 września 1944] $]^{61}$.

W 1944 roku odesłano Natalię z wyrokiem śmierci do obozu w Ravensbrück. Organizowała tu spotkania literackie, recytowała wiersze i żarliwie się modliła. Uczyła gimnazjalistki, które trafiły do obozu wprost z powstania warszawskiego. Notowała na skrawkach papieru liczne tytuły lektur, które jej zdaniem powinny przeczytać, gdy wyjdą na wolność. Snuła plany na przyszłość, chciała po zakończeniu wojny pracować w radio. W Wielki Piątek 30 marca 1945 roku podczas ostatniej selekcji w obozie zakwalifikowano Natalię do stracenia, a 31 marca 1945 roku w komorze gazowej dokonało się jej życie. Kilka godzin później wojska alianckie i rosyjskie wyzwalały obóz ${ }^{62}$. Swiętość Natalii Tułasiewicz będąca odpowiedzią na ekstremalne doświadczenie II wojny światowej dojrzewała przez lata studiów i pracy nauczycielskiej, przez miłość do wychowanków i miłość do Ojczyzny, przez pasje muzyczne i literackie ${ }^{63}$.

Na koniec warto zaznaczyć, że świeccy błogosławieni Archidiecezji Poznańskiej to dwoje pedagogów i pięcioro wychowanków. Bojanowski zaproponował koncepcję wychowania integralnego polegającego na oddziaływaniu wychowawczym na wszystkie sfery życia wychowanka. Tułasiewiczówna realizowała pedagogikę połączoną z otwarciem na piękno świata i pasją poznawania go oraz wizją świeckiego apostolstwa. Poznańska Piątka została wychowana na systemie prewencyjnym św. Jana Bosko, polegającym na zaniechaniu karania na rzecz mądrej miłości i towarzyszenia wychowankom. Ich życiorysy to ważna pomoc na trudne dla kwestii wychowania czasy. Przedstawione postacie łączą także głębokie uczucia patriotyczne. Bojanowski wpisał wychowanie patriotyczne w swój program wychowawczy, Natalia pisała, że „miłuje Ojczyznę jak duszę własną”"64, a chłopcy z Poznańskiej Piątki przez działalność konspiracyjną i wierność do końca złożyli Ojczyźnie najwyższą ofiarę. Wszyscy pozostawili po sobie liczne

${ }^{61}$ Tamże, s. 232.

${ }^{62}$ Zob. B. Judkowiak, Błogosławiona Natalia Tułasiewicz [w:] ,,Nasze czasy wołają o świętych nauczycieli”. 70. Ogólnopolska Pielgrzymka Nauczycieli i Wychowawców. Jasna Góra, 30 czerwca-1 lipca 2007, red. E. Jankiewicz, Zielona Góra 2007, s. 35.

${ }_{63}$ Por. J. Podlaszczak, Trudne czasy...

${ }^{64}$ N. Tułasiewicz, Poprzez ziemię ukochałam niebo..., s. 69. 
zapiski pamiętnikarskie, z których wyłaniają się realistycznie odmalowane charaktery. Dotychczas wydano opracowane cztery tomy Dziennika Edmunda Bojanowskiego ${ }^{65}$, dwa tomy jego notatek pedagogicznych ${ }^{66} \mathrm{i}$ dwa tomy korespondencji $^{67}$. W przypadku Natalii Tułasiewiczówny z siedmiu tomów pamiętnikarskich notatek, jakie powstawały od 1934 roku, zachowały się cztery: zapiski od 1938 do sierpnia 1943 roku $^{68}$. Odnośnie do Poznańskiej Piątki posiadamy Dzienniczek Edy Kaźmierskiego oraz kilkadziesiąt listów do rodziny, przyjaciół i znajomych z czasu więzienia ${ }^{69}$.

Jeszcze bliżsi współczesnemu czytelnikowi stają się błogosławieni świeccy Archidiecezji Poznańskiej z racji zachowanych materiałów fotograficznych. Jedyne zachowane zdjęcie błogosławionego Edmunda przedstawia dojrzałego mężczyznę z bujnym zarostem na twarzy, zadbanego i elegancko ubranego. Dostępne zdjęcia Piątki przedstawiają przystojnych młodzieńców pełnych życia i energii, modnie ubranych i uczesanych. Niektóre dokumentują żarty i chłopięce wybryki wychowanków Oratorium Salezjańskiego. Liczne zdjęcia Natalii przedstawiają młodą, uśmiechniętą, atrakcyjną, dobrze ubraną kobietę na wycieczce z uczennicami, na nartach, podczas wyprawy w góry czy spaceru po mieście. Niemożliwe do zamknięcia w ramach jednego opracowania bogactwo osobowości i czynów świeckich błogosławionych Archidiecezji Poznańskiej najlepiej wyrażają słowa św. Jana Pawła II na zakończenie homilii beatyfikacyjnej:

Raduj się, Polsko, z nowych błogosławionych [...] Spodobało się Bogu „wykazać przemożne bogactwo Jego łaski na przykładzie dobroci” twoich synów i córek w Chrystusie Jezusie (por. Ef 2,7). Oto „bogactwo Jego łaski”, oto fundament naszej niewzruszonej ufności w zbawczą obecność Boga na drogach człowieka w trzecim tysiącleciu!

\section{Sanctity for the Lay People. The Blessed of the Archdiocese of Poznań}

\section{Summary}

The article shows the profiles of the seven blessed of the Archdiocese of Poznan, and passages from their memoirs. The author tries to discover the timeless features of the secular model of sanctity in the hagiographies of Edmund Bojanowski, Czesław Jóźwiak, Franciszek Kęsy, Edward Kaźmierski, Jarogniew Wojciechowski, Edward Klinik and Natalia Tułasiewiczówna. The article shows in

${ }^{65}$ E. Bojanowski, Dziennik..., tom 1-4.

${ }^{66}$ Prace, szkice i notatki Edmunda Bojanowskiego. Inedita, t. II, red. E. Gigilewicz, M.L. Opiela, Lublin 2016. 2001.

${ }^{67}$ Korespondencja Edmunda Bojanowskiego z lat 1829-1871, t. 1-2, red. L. Smolka, Wrocław

${ }^{68}$ por. D. Tułasiewicz, B. Judkowiak, Przeciw barbarzyństwu ..., s. 11.

${ }^{69}$ M. Tadrzak-Mazurek, Zwyczajni święci..., s. 156-207. 
each of the seven biographies the path of gradual maturation in faith embedded in the historical context of events crucial for Poland. A common feature of all the characters is their strong commitment to the cause of education and patriotism based on a solid religious and moral foundation.

\section{Keywords}

Edmund Bojanowski, Czesław Jóźwiak, Franciszek Kęsy, Edward Kaźmierski, Jarogniew Wojciechowski, Edward Klinik, Natalia Tułasiewiczówna, sanctity, secular, education, teaching, patriotism

\section{Słowa kluczowe}

Edmund Bojanowski, Czesław Jóźwiak, Franciszek Kęsy, Edward Kaźmierski, Jarogniew Wojciechowski, Edward Klinik, Natalia Tułasiewiczówna, świętość, świecki, wychowanie, nauczanie, patriotyzm

\section{Bibliografia}

Bojanowski E., Dziennik 1853-1871, red. A. i T. Szafrańscy, Warszawa 1999.

Bojanowski E., Dziennik, Wrocław 2009.

Chávez P., Zwiastunowie poranka, „Don BOSCO. Magazyn salezjański”, 7/8 (2002), s. 2.

Grocholewski Z., Bt. Edmund Bojanowski. W dynamizmie twórczej miłości, Poznań 2014.

Grün A., O duchowości inaczej, tłum. K. Zimmerer, Kraków 1996.

Jan Paweł II, Homilia podczas Mszy Świętej beatyfikacyjnej w Warszawie 13 czerwca 1999, Opoka, 24 czerwca 1999, [online] https://opoka.org.pl/biblioteka/W/WP/jan_pawel_ii/homilie/warszawa_13061999.html [21.03.2018].

Judkowiak B., Błogosławiona Natalia Tułasiewicz [w:] „Nasze czasy wołaja o świętych nauczycieli”. 70. Ogólnopolska Pielgrzymka Nauczycieli i Wychowawców. Jasna Góra, 30 czerwca-1 lipca 2007, red. E. Jankiewicz, Zielona Góra 2007, s. 35.

Judkowiak B., ,Przyjmij mnie na nowo do swej klasy (nauczyciele ,w szkole” błogostawionej Natalii) [w:] B. Judkowiak, T. Marchwiak, S. Sławiński, K. Szablak, Blask świadectwa. Błogosławiona nauczycielka Natalia Tułasiewicz, Poznań 2013, s. 11-43.

Judkowiak B., Marchwiak T., Sławiński S., Szablak K., Blask świadectwa. Błogosławiona nauczycielka Natalia Tułasiewicz, Poznań 2013.

Korespondencja Edmunda Bojanowskiego z lat 1829-1871, t. 1-2, red. L. Smolka, Wrocław 2001.

Krawiec J., Błogosławieni świadkowie Chrystusa, Kraków 2000.

Maj A., Współczesny kontekst katechetyczny idei pedagogicznych błogosławionego Edmunda Bojanowskiego, materiały z sympozjum Aktualność idei pedagogicznych błogosławionego Edmunda Bojanowskiego i ich implikacje katechetyczne, Poznań 2012.

Mikuła J., Jak wychować świętych, „Don BOSCO. Magazyn salezjański” 6 (2006), s. 4.

Opiela M., Integralna Pedagogika Przedszkolna w systemie wychowania Edmunda Bojanowskiego. Kontynuacja i zmiana, Lublin 2013.

Podlaszczak J., Trudne czasy rodza świętych nauczycieli, „Kwartalnik Edukacyjny” 4 (2007), s. $67-72$.

Prace, szkice i notatki Edmunda Bojanowskiego. Inedita, t. II, red. E. Gigilewicz, M.L. Opiela, Lublin 2016. 
Rzesoś A., Błogosławiona Natalia Tułasiewicz. Droga do Męczeństwa (rozprawa doktorska), AMUR - Adam Mickiewicz University Repository, 23 listopada 2015, [online] https://repozytorium.amu.edu.pl//handle/10593/14036 [23.07.2018].

Sierchuła R., Wąsowicz J., Wierni do końca: studia i materiały źródtowe o „Poznańskiej Piątce” męczenników II wojny światowej, Poznań 2012.

Tadrzak-Mazurek M., Zwyczajni święci, Poznań 2014.

Tułasiewicz D., Judkowiak B., Przeciw barbarzyństwu. Listy — Dzienniki — Wspomnienia, Poznań 2013.

Tułasiewicz N., Poprzez ziemię ukochałam niebo: fragmenty zapisków 1938-1943, Poznań 2015.

Wiśniewska J., Bt. Edmund Bojanowski. Świecki mężczyzna i... zakon dla kobiet, stacja7.pl, 7 sierpnia 2017, [online] https://stacja7.pl/swieci/bl-edmund-bojanowski-swiecki-mezczyzna-zakon-dla-kobiet/ [21.03.2018]. 